Check for updates

Cite this: RSC Adv., 2019, 9, 33755

Received 29th August 2019

Accepted 16th October 2019

DOI: 10.1039/c9ra06869d

rsc.li/rsc-advances

\section{Effect of salts formed by neutralization for the enzymatic hydrolysis of cellulose and acetone- butanol-ethanol fermentation}

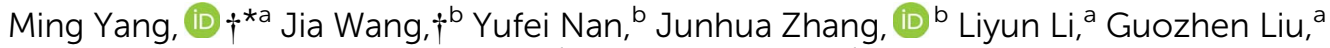 \\ Jouko Vepsäläinen, ${ }^{c}$ Suvi Kuittinen ${ }^{d}$ and Ari Pappinen ${ }^{d}$
}

\begin{abstract}
Neutralization is essential to maintain the $\mathrm{pH}$ for enzymatic hydrolysis of cellulose followed by fermentation of biofuels. This study investigated the effect of salts formed during the neutralization on the enzymatic hydrolysis of cellulosic materials and acetone-butanol-ethanol (ABE) fermentation. The results showed that the formed $\mathrm{Ca}$-citrate salt considerably decreased the glucose release by $26.9 \%$ and $26.1 \%$ from Avicel and sulfuric acid-pretreated hybrid Pennisetum, respectively, which was probably due to the unproductive adsorption of cellulases by $\mathrm{Ca}$-citrate solids. On the other hand, the formed soluble $\mathrm{Na}$ and $\mathrm{Ca}$ salts severely inhibited ABE fermentation, thereby decreasing the ABE concentration from $12.8 \mathrm{~g}$ $\mathrm{L}^{-1}$ to $0-10.7 \mathrm{~g} \mathrm{~L}^{-1}$ in different degrees, but no or slight inhibition was observed when the Ca salts formed as precipitates. In particular, Ca-sulfate did not show apparent inhibition of both hydrolysis and fermentation. Therefore, the selection of suitable pretreatment and neutralizing reagents is an alternative way to avoid process inhibition in biofuel production from lignocellulosic materials.
\end{abstract}

\section{Introduction}

Economic growth has naturally led to a rapid rise in energy consumption worldwide. The increasing demand for biofuels has been the impetus for research to produce alcohol biofuels from renewable resources. ${ }^{1,2}$ Biobutanol with superior fuel properties is considered as an alternative biofuel. ${ }^{3,4}$ It could be produced through acetone, butanol, and ethanol (ABE) fermentation by Clostridium strains from lignocellulosic materials such as agricultural and forest residues, and energy crops. $^{5-8}$ Lignocellulose mainly consists of cellulose, hemicellulose, and lignin, which form a complex structure to resist the chemical or microbial degradation. Thus, the conversion of lignocellulosic materials to sugars for ABE fermentation is one of the main technical and economic challenges.

Enzymatic hydrolysis represents the most-efficient method for conversion of lignocellulosic materials to fermentable sugars. ${ }^{9}$ Pretreatment necessarily disrupts the heterogeneous structure of lignocellulosic materials, removes hemicelluloses

${ }^{a}$ College of Life Sciences, Hebei Agricultural University, Baoding 071001, Hebei, China. E-mail:shmym@hebau.edu.cn

${ }^{b}$ College of Forestry, Northwest A\&F University, 3 Taicheng Road, Yangling 712100, Shaanxi, China

'School of Pharmacy, University of Eastern Finland, P.O. Box 1627, FI70211 Kuopio, Finland

${ }^{d}$ School of Forest Sciences, University of Eastern Finland, P.O. Box 111, FI80101 Joensuu, Finland

$\dagger$ Equally contributed by both authors in this article. and/or lignin, and increases the surface area and porosity of biomass. ${ }^{\mathbf{1 0 , 1 1}}$ Therefore, pretreatment enhances the enzymatic hydrolysis of cellulose for biofuels fermentation. ${ }^{12}$ To date, a variety of pretreatment technologies have been developed. Dilute acid and alkali pretreatments are the most widely used pretreatment processes, which yield higher amounts of digestible substrates for successful enzymatic hydrolysis. ${ }^{13}$

After dilute acid or alkali pretreatment, a neutralization step is essential to maintain the required $\mathrm{pH}$ for the enzymatic hydrolysis of cellulosic materials followed by fermentation to biofuels. Generally, alkalis (i.e., sodium hydroxide, calcium hydroxide, ammonia, and calcium carbonate) or acids (i.e., sulfuric, acetic, and hydrochloric acids) are used to neutralize the pretreated hydrolysate to $\mathrm{pH} 5.0$ and 6.5 for enzymatic hydrolysis and fermentation, respectively. However, salts, such as $\mathrm{Na}$ and $\mathrm{Ca}$ salts, formed during the neutralization process, might affect the efficiency of hydrolysis and fermentation. Several studies have shown that soluble salts, including sodium sulfate, sodium acetate, and sodium chloride, were toxic to butanol-producing cultures. ${ }^{14,15}$ The presence of soluble salts in the fermentation medium inhibits the cell growth of fermentation microbes. ${ }^{16}$

To the best of our knowledge, few studies discussed the effect of salts formed after neutralization on enzymatic hydrolysis of cellulosic materials. It is also unclear whether insoluble salts have inhibitory effects on ABE fermentation. This study simulated the formation process of salts after sulfuric, acetic, and citric acid pretreatments to investigate the effect of these salts on enzymatic hydrolysis of cellulosic materials and 
acetone-butanol-ethanol (ABE) fermentation, respectively. The study will provide a scientific basis for adjusting biomass processing conditions to increase the feasibility of biofuel production from lignocellulosic materials.

\section{Experimental}

\section{Raw materials}

The hybrid Pennisetum used as a lignocellulosic material was provided by the Beijing Research and Development Center for Grass and Environment, Beijing Academy of Agriculture and Forestry Sciences, Beijing, China. The raw materials were milled and sieved through a 80 mesh screen scale. The milled sample was pretreated with $1 \%(\mathrm{w} / \mathrm{w})$ sulfuric acid with a solid to liquid ratio of $1: 10$ at $121{ }^{\circ} \mathrm{C}$ for $1 \mathrm{~h}$ in an autoclave (YXQ-LS-50A, Boxun, Shanghai). After pretreatment, the supernatant and solid were separated by centrifugation at $10000 \mathrm{~g}$ for $10 \mathrm{~min}$. The pretreated solids were washed and oven-dried at $105{ }^{\circ} \mathrm{C}$ for $12 \mathrm{~h}$, and then were used for enzymatic hydrolysis. Microcrystalline cellulose (Avicel PH-101) was purchased from Sigma Chemical Co. (St. Louis, MO, USA). The Avicel and pretreated Pennisetum contained $91.3 \%$ and $51.7 \%$ cellulose, respectively. The commercial enzymes Celluclast $1.5 \mathrm{~L}$ and Novozyme 188 (Novozymes A/S, Bagsværd, Denmark) were used as the cellulase preparations (CEL). Clostridium acetobutylicum DSM 1731 was obtained from DSMZ, Braunschweig Germany (German Collection of Microorganisms and Cell Cultures).

\section{Enzymatic hydrolysis}

Hydrolysis with $2 \%(\mathrm{w} / \mathrm{v})$ Avicel and sulfuric acid-pretreated hybrid Pennisetum was performed in tubes with $3 \mathrm{~mL}$ buffer solution in a shaker with stirring at $200 \mathrm{rpm}, 50{ }^{\circ} \mathrm{C}$ for $48 \mathrm{~h}$. The sodium citrate buffer (50 mM, pH 5.0) was used as control. The citric acid, acetic acid, and sulfuric acid solutions, which were neutralized with $\mathrm{NaOH}$ and $\mathrm{Ca}(\mathrm{OH})_{2}$ to $\mathrm{pH} 5.0$, respectively, were also used as buffer for the hydrolysis. Dilute acid pretreatments are usually performed over a temperature range of $120{ }^{\circ} \mathrm{C}$ to $210{ }^{\circ} \mathrm{C}$, with acid concentration typically less than $4 \%(\mathrm{w} / \mathrm{w})$ and residence time from a few seconds to an hour in different types of reactors. ${ }^{13}$ Thus, the acids loading, $90 \mathrm{mM}$ and $120 \mathrm{mM}$, were applied according to the studies, in which different dilute organic acids were used for pretreatments. ${ }^{17-19}$ Prior to the hydrolysis, $22.9 \mathrm{mg}$ protein per $\mathrm{g}$ biomass of Celluclast $1.5 \mathrm{~L}$ (169.6 $\mathrm{mg}$ protein per $\mathrm{mL}), 18.3 \mathrm{mg}$ protein per $\mathrm{g}$ biomass of Novozyme 188 (187.9 mg protein per $\mathrm{mL}$ ) were added to the slurry for enzymatic hydrolysis. After the hydrolysis, the samples were boiled for $10 \mathrm{~min}$ to stop the enzymatic hydrolysis and then centrifuged for $10 \mathrm{~min}$ at $10000 \mathrm{~g}$. The supernatant of each sample was collected for glucose analysis.

\section{Enzyme adsorption}

The enzyme adsorption experiments were carried out in sodium citrate buffer $(50 \mathrm{mM}, \mathrm{pH} 5.0)$ with $1 \%(\mathrm{w} / \mathrm{v})$ consistency of Cacitrate or Ca-sulfate salts. The samples were incubated with 10$400 \mathrm{mg}$ protein of enzymes per $\mathrm{g}$ dry matter for $60 \mathrm{~min}$ at $4{ }^{\circ} \mathrm{C}$ with magnetic stirring. After adsorption, the solids and liquids were separated by centrifugation at $10000 \mathrm{~g}$ for $10 \mathrm{~min}$. The protein concentration was measured with a BCA protein assay kit (Beyotime biotechnology, China). The protein adsorbed was measured by subtracting the protein in supernatant from the total loaded protein.

\section{Fermentation}

Freeze-stored culture of Clostridium acetobutylicum DSM 1731 was inoculated to $50 \mathrm{~mL}$ of Reinforced Clostridial Medium ${ }^{20}$ for 14-16 $\mathrm{h}$. Then, $1 \mathrm{~mL}$ of active growing cells was inoculated into $50 \mathrm{~mL}$ of sterilized pre-fermentation P2 media prepared in a $125 \mathrm{~mL}$ screw-capped bottle. The pre-fermentation P2 medium contained glucose $30 \mathrm{~g} \mathrm{~L}^{-1}$ and yeast extract $1 \mathrm{~g} \mathrm{~L}^{-1}$. Before inoculation, $0.5 \mathrm{~mL}$ each of the filter-sterilized stock solution (buffer: $\mathrm{KH}_{2} \mathrm{PO}_{4} 50 \mathrm{~g} \mathrm{~L}^{-1}, \mathrm{~K}_{2} \mathrm{HPO}_{4} 50 \mathrm{~g} \mathrm{~L}^{-1}$, ammonium acetate $220 \mathrm{~g} \mathrm{~L}$; mineral: $\mathrm{MgSO}_{4} \cdot 7 \mathrm{H}_{2} \mathrm{O} 20 \mathrm{~g} \mathrm{~L}^{-1}, \mathrm{MnSO}_{4^{-}}$ $\cdot \mathrm{H}_{2} \mathrm{O} 1 \mathrm{~g} \mathrm{~L}^{-1}, \mathrm{FeSO}_{4} \cdot 7 \mathrm{H}_{2} \mathrm{O} 1 \mathrm{~g} \mathrm{~L}^{-1}, \mathrm{NaCl} 1 \mathrm{~g} \mathrm{~L}$; and vitamin: para-aminobenzoic acid $0.1 \mathrm{~g} \mathrm{~L}^{-1}$, thiamine $0.1 \mathrm{~g} \mathrm{~L}^{-1}$, biotin $0.001 \mathrm{~g} \mathrm{~L}^{-1}$ ) was added into the P2 media. The culture was allowed to grow for approximately $16 \mathrm{~h}$ at $37{ }^{\circ} \mathrm{C}$ before inoculation into the ABE fermentation media.

ABE fermentation was conducted in a $125 \mathrm{~mL}$ screw-capped bottle containing $50 \mathrm{~mL}$ glucose medium, in which the original glucose concentration was $50 \mathrm{~g} \mathrm{~L}^{-1}$. The media containing 90 and $120 \mathrm{mM}$ citric acid, acetic acid, and sulfuric acid were neutralized with $\mathrm{NaOH}$ and $\mathrm{Ca}(\mathrm{OH})_{2}$ to $\mathrm{pH} 6.5$, respectively. The media were boiled for $10 \mathrm{~min}$ in the water bath and purged with $\mathrm{N} 2$ for 2 min to maintain their anaerobic condition, and then sterilized at $121{ }^{\circ} \mathrm{C}$ for $15 \mathrm{~min}$. Fermentation started at $37{ }^{\circ} \mathrm{C}$ when the media were inoculated into the $C$. acetobutylicum DSM 1731 culture $(10 \%, v / v)$. Each of the filter-sterilized stock solutions (buffer, mineral and vitamin) was added to the media before the inoculation. All fermentations were conducted at least twice to ensure the reproducibility.

\section{Chemical analysis}

The hydrolysis and fermentation samples were analyzed using nuclear magnetic resonance (NMR). The NMR spectra for quantification of glucose, butanol, acetone and ethanol were recorded on an AVANCE 500 DRX NMR spectrometer equipped with a $5 \mathrm{~mm}$ QNP SB probe (Bruker, Billerica, MA, USA). The above-mentioned compounds were identified from routine twodimensional proton-proton and proton-carbon correlated spectra. Quantitative 1H NMR spectra were collected with water presaturation (zgcppr) using a $90^{\circ}$ pulse angle, $48 \mathrm{~dB}$ presaturation power, $40 \mathrm{~s}$ relaxation delay, and $16 \mathrm{scans}$ at $300 \mathrm{~K}$. Prior to the NMR measurements, $200 \mathrm{~L}$ of sample liquid was transferred to a $5 \mathrm{~mm}$ NMR tube followed by addition of deuterium oxide $\left(\mathrm{D}_{2} \mathrm{O}, 275 \mathrm{~L}\right)$ and 3-(trimethylsilyl)-propionic- $\mathrm{d}_{4}$ acid $(25 \mathrm{~L}$, $20 \mathrm{mM}$ ) in $\mathrm{D}_{2} \mathrm{O}$ as an internal standard of known concentration.

\section{Calculations}

Glucose yields were calculated based on the chemical composition of Avicel and pretreated HP according to eqn (1). Butanol and $\mathrm{ABE}$ yields were calculated based on the fermentation 
products, and the original and residual glucose concentrations in fermentation media according to eqn (2).

Glucose yield $\quad(\%)=\frac{\text { glucose released }(\mathrm{g}) \times 0.9}{\text { cellulose content in substrates }(\mathrm{g})} \times 100$ salts did not affect the glucose yields after hydrolysis of both Avicel and sulfuric acid-pretreated hybrid Pennisetum (Table 1).

Previously, it was reported that in the presence of $\mathrm{Na}_{2} \mathrm{SO}_{4}$, $\mathrm{K}_{2} \mathrm{SO}_{4}, \mathrm{CaSO}_{4}$, and $\left(\mathrm{NH}_{4}\right)_{2} \mathrm{SO}_{4}$ salts, the enzymatic hydrolysis yields of washed acid-catalyzed steam-exploded corn stover gradually decreased with increasing salts concentrations. ${ }^{21}$ The inhibition degree of $\mathrm{CaSO}_{4}$ was the highest at $0.06 \mathrm{M}$, whereas

$$
\text { Butanol or } \mathrm{ABE} \text { yield }=\frac{\text { butanol or } \mathrm{ABE} \text { concentration }\left(\mathrm{g} \mathrm{L}^{-1}\right)}{\text { original-residual glucose concentration }\left(\mathrm{g} \mathrm{L}^{-1}\right)}
$$

\section{Results and discussion}

\section{Effect of salts on enzymatic hydrolysis}

The hydrolysis of Avicel and sulfuric acid-pretreated hybrid Pennisetum in Na-citrate (50 $\mathrm{mM}$ ) buffer as control and in pure water was conducted (Fig. 1). There were no apparent differences in glucose concentrations after Avicel hydrolysis between Na-citrate buffer and water. However, the glucose concentration with water for hybrid Pennisetum was slightly lower. When the original citric acid concentration was 90 or $120 \mathrm{mM}$, the Nacitrate formed after neutralization by $\mathrm{NaOH}$ did not affect glucose release after hydrolysis. However, Ca-citrate that formed after neutralization by $\mathrm{Ca}(\mathrm{OH})_{2}$ decreased the glucose yields of Avicel and sulfuric acid-pretreated hybrid Pennisetum from $30.6 \%$ and $31.8 \%$ to $3.7 \%$ and $5.7 \%$, respectively (Fig. 1 ). The glucose yields of these two materials were inhibited by $26.9 \%$ and $26.1 \%$, respectively, according to the calculation of decreased percentage of glucose yields compared to control. The concentrations of salts did not make the differences in glucose yields. When sulfuric acid and acetic acid were present, the formed Na-sulfate, Ca-sulfate, Na-acetate, and Ca-acetate

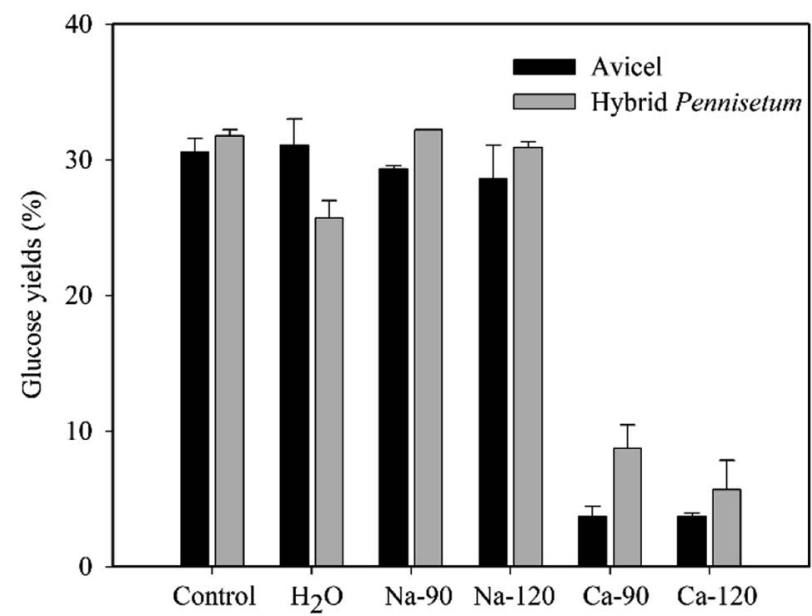

Fig. 1 Glucose concentrations after enzymatic hydrolysis of Avicel and sulfuric acid-pretreated hybrid Pennisetum when $\mathrm{Na}$-citrate and Ca-citrate were present. The 90 and $120 \mathrm{mM}$ represents the concentration of citric acid originally in the hydrolysis solution. that of $\left(\mathrm{NH}_{4}\right)_{2} \mathrm{SO}_{4}$ was the lowest. ${ }^{11}$ The reason was probably due to that the combination of $\mathrm{Ca}^{2+}$ and $-\mathrm{SH}$ of the cystine residue in cellulase activity centre inhibited the cellulase activity; moreover, $\mathrm{Ca}^{2+}$, as a divalent metal ion, could have more effect on the conformation deformation of the cellulase molecular structure, resulting in inhibition effect on its activity. ${ }^{22}$ In an another study, Yu et al. (2010) found that the common cations of ash $\left(\mathrm{K}^{+}, \mathrm{Mg}^{2+}, \mathrm{Ca}^{2+}, \mathrm{Al}^{3+}, \mathrm{Mn}^{2+}, \mathrm{Fe}^{3+}, \mathrm{Cu}^{2+}\right.$, and $\left.\mathrm{Zn}^{2+}\right)$ all showed inhibitory effects on cellulase at different levels, except for the stimulative effects of $\mathrm{Ca}^{2+}$ and $\mathrm{Mg}^{2+}$ on $\beta$-glucosidase. ${ }^{23}$ The results in this study showed that only Ca-citrate had an inhibitory effect on the enzymatic hydrolysis of cellulosic materials. This suggested that the $\mathrm{Na}^{+}$and $\mathrm{Ca}^{2+}$ was probably not the inhibitors for enzymatic hydrolysis of cellulosic materials by cellulase.

The inhibition of Ca-citrate was probably due to the unproductive adsorption of enzymes on the Ca-citrate solid particles. As can be seen, the Ca-citrate decreased the amount of free enzymes in solution by adsorption (Fig. 2). This result was in agreement with the study of interactions of enzymes and $\mathrm{CaCO}_{3}{ }^{24}$ The enzymes' adsorption capacity of Ca-sulfate was apparently lower than for Ca-citrate, which was probably because of its slight solubility. The enzyme-binding mechanism for Ca-citrate has not been studied previously. A clue to its operative mechanism can be deduced from analogous mechanistic studies of enzyme-lignin interactions. ${ }^{25}$ This unproductive adsorption could be due to hydrophobic, hydrogen bond, and electrostatic interactions. ${ }^{24}$ The enzyme-Ca-citrate interaction mechanisms could be explained by electrostatic and hydrogen bond interactions because Ca-citrate is generally considered to present a hydrophilic surface.

\section{Effect of salts on ABE fermentation}

When the glucose medium contained $90 \mathrm{mM}$ citric acid originally, the fermentation after neutralization by $\mathrm{Ca}(\mathrm{OH})_{2}$ produced $13.2 \mathrm{~g} \mathrm{~L}^{-1} \mathrm{ABE}$ in $120 \mathrm{~h}$, in which $8.3 \mathrm{~g} \mathrm{~L}^{-1}$ was butanol (Fig. 3A). The butanol and ABE yields were 0.21 and 0.33 , respectively (Table 2). The concentrations of acetone, butanol and ethanol, and yields of these solvents were comparable to the control experiment without any salts. The solvents yields were also in agreement with previous studies. ${ }^{26-28}$ The increased concentration $(120 \mathrm{mM})$ of citric acid did not affect 
Table 1 Glucose concentrations after enzymatic hydrolysis of Avicel and sulfuric acid-pretreated hybrid Pennisetum when $\mathrm{Na}$ and $\mathrm{Ca}$ salts were present

Glucose yields (\%)

Salts Concentrations (mM) Avicel Hybrid Pennisetum
$\mathrm{H}_{2} \mathrm{O}$

Na-citrate buffer 50

Na-sulfate $\quad 90$

Na-acetate 90

120

Ca-acetate 90

120 $\begin{array}{ll} & 120 \\ \text { Ca-sulfate } & 90\end{array}$

120
$31.1 \pm 2.025 .7 \pm 1.3$

$30.6 \pm 1.0 \quad 31.8 \pm 0.4$

$31.8 \pm 1.7 \quad 32.2 \pm 0.0$

$27.9 \pm 0.7 \quad 30.9 \pm 0.4$

$29.3 \pm 0.3 \quad 32.2 \pm 0.0$

$29.1 \pm 1.5 \quad 31.3 \pm 0.0$

$29.1 \pm 1.531 .8 \pm 1.3$

$26.4 \pm 1.7 \quad 25.2 \pm 3.5$

$27.6 \pm 1.531 .3 \pm 0.8$

$29.3 \pm 0.7 \quad 30.9 \pm 0.4$ the ABE fermentation. However, C. acetobutylicum DSM1731 did not grow when Na-citrate formed after neutralization by $\mathrm{NaOH}$, which suggested that Na-citrate inhibited the fermentation. When Na-acetate and Na-sulfate formed, the butanol and ABE concentrations and yields after fermentation were apparently lower than control (Fig. 3B and $\mathrm{C}$ and Table 2).

The results suggested that the Na salts had a severe inhibitory effect on ABE fermentation by C. acetobutylicum DSM1731 and the order of the inhibitory effect was Na-citrate $>$ Na-acetate $>$ Na-sulfate. The inhibition of soluble Na salts was in accordance with the previous studies. Ezeji et al. (2007) reported that ABE concentrations decreased by $4.5 \mathrm{~g} \mathrm{~L}^{-1}$ and $6.5 \mathrm{~g} \mathrm{~L}^{-1}$ when Na-acetate $\left(13.3 \mathrm{~g} \mathrm{~L}^{-1}\right)$ and an additional Na-sulfate $\left(8.9 \mathrm{~g} \mathrm{~L}^{-1}\right)$ were present in the fermentation medium. ${ }^{\mathbf{1 4}}$ Thus, a mixture of salts could be more toxic than a single salt. As reported previously, C. beijerinckii P260 produced less than $2.59 \mathrm{~g} \mathrm{~L}^{-1} \mathrm{ABE}$ from alkaline peroxide-treated wheat straw hydrolysate without detoxification. ${ }^{29}$ After the removal of salts using electrodialysis, however, the ABE concentration increased to $22.17 \mathrm{~g} \mathrm{~L}^{-1} .^{29}$ The

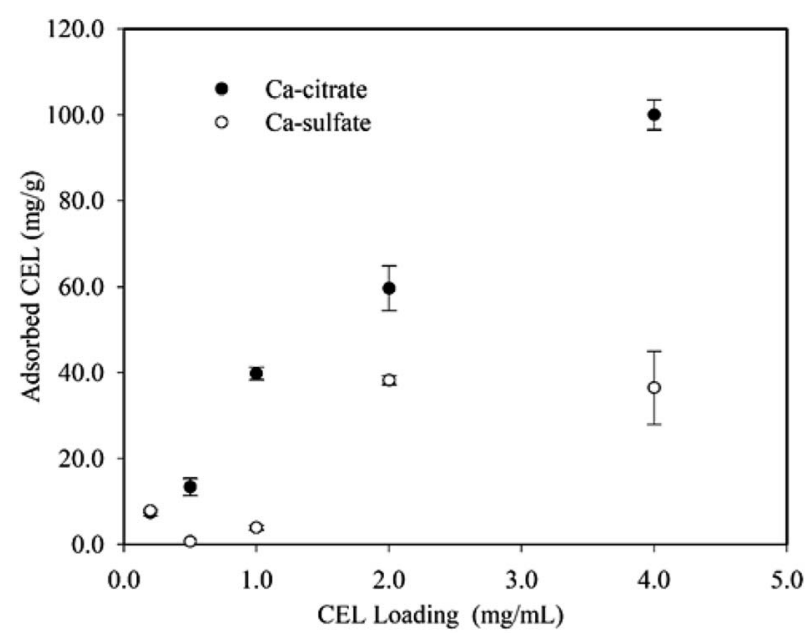

Fig. 2 Adsorption of cellulase preparation (CEL) by Ca-citrate and Casulfate. presence of these inhibitors might affect microbial cell growth and inhibit the glycolytic and fermentative enzymes, which are essential to central metabolic pathways. ${ }^{30}$

When Ca-acetate and Ca-sulfate formed after neutralization by $\mathrm{Ca}(\mathrm{OH})_{2}$, increased concentrations and yields of solvents were obtained after fermentation compared to that with $\mathrm{Na}$ salts (Fig. 2B and C and Table 2). Similarly to Ca-citrate, Ca-sulfate produced comparable concentrations and yields of solvents to
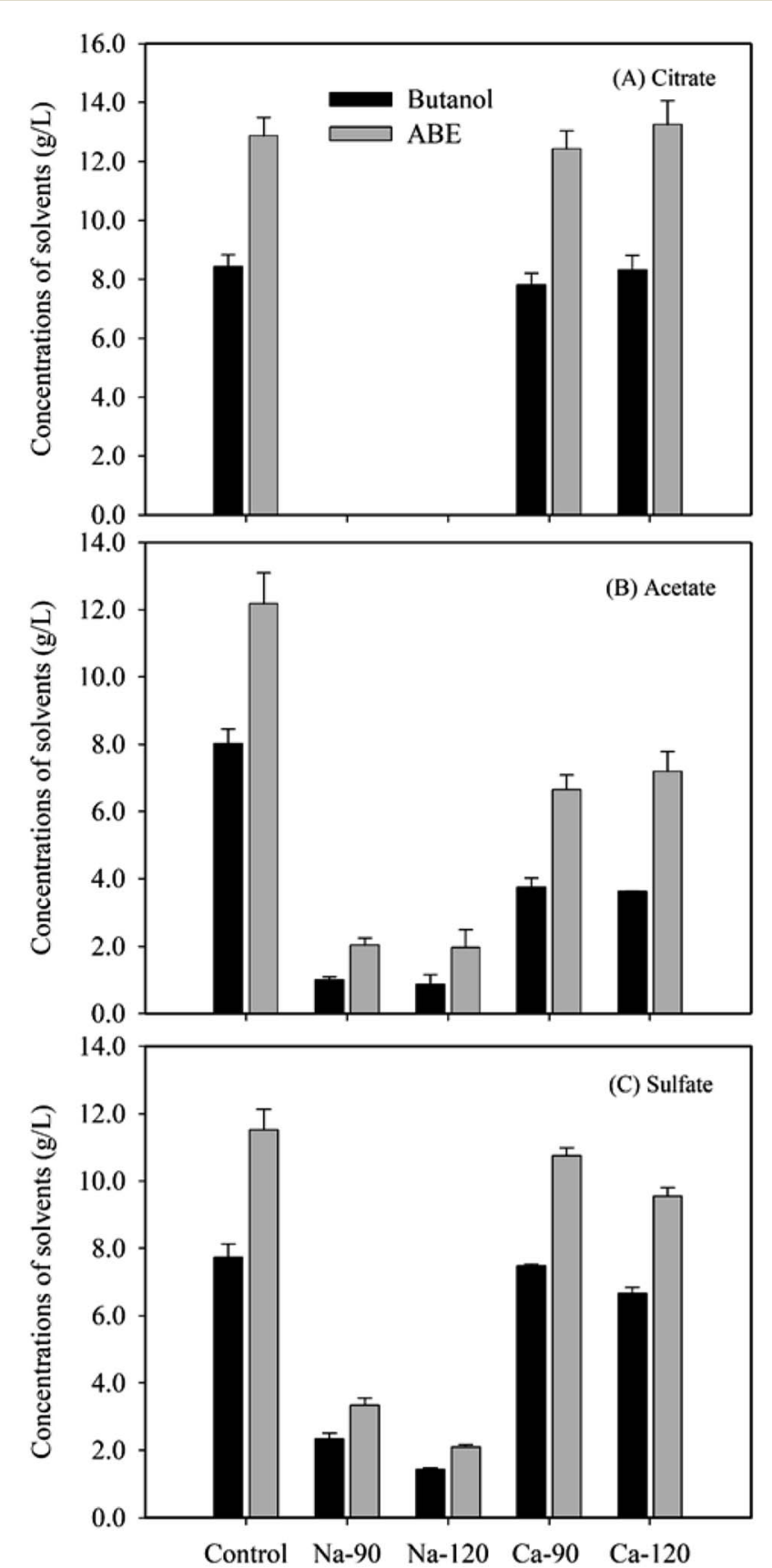

Fig. 3 Concentrations of butanol and $A B E$ after glucose fermentation by $C$. acetobutylicum DSM 1731 when (A) Na-citrate and Ca-citrate, (B) $\mathrm{Na}$-acetate and $\mathrm{Ca}$-acetate, and (C) Na-sulfate and Ca-sulfate were present in the medium. The 90 and $120 \mathrm{mM}$ represents the concentration of citric, acetic, and sulfuric acid originally in the fermentation media. 
Table 2 Concentrations of acetone, butanol and ethanol, and yields of butanol and ABE after glucose fermentation by C. acetobutylicum DSM 1731 when $\mathrm{Na}$ and $\mathrm{Ca}$ salts were present in the media. The 90 and $120 \mathrm{mM}$ represents the concentration of citric, acetic, and sulfuric acid originally in the fermentation media

\begin{tabular}{|c|c|c|c|c|c|c|c|c|c|}
\hline \multirow[b]{2}{*}{ Salts } & \multirow[b]{2}{*}{ Concentration (mM) } & \multicolumn{4}{|c|}{ Products $\left(\mathrm{g} \mathrm{L}^{-1}\right)$} & \multicolumn{2}{|c|}{ Glucose $\left(\mathrm{g} \mathrm{L}^{-1}\right)$} & \multicolumn{2}{|c|}{ Yields $\left(\mathrm{g} \mathrm{g}^{-1}\right)$} \\
\hline & & Acetone & Butanol & Ethanol & $\mathrm{ABE}$ & Original & Residual & Butanol & $\mathrm{ABE}$ \\
\hline Control & 0 & $3.4 \pm 0.2$ & $8.4 \pm 0.4$ & $1.1 \pm 0.1$ & $12.8 \pm 0.6$ & $49.9 \pm 0.4$ & $7.7 \pm 1.7$ & 0.20 & 0.30 \\
\hline \multirow[t]{2}{*}{ Ca-citrate } & 90 & $3.7 \pm 0.2$ & $7.8 \pm 0.4$ & $1.0 \pm 0.1$ & $12.4 \pm 0.6$ & $43.9 \pm 0.0$ & $6.3 \pm 1.7$ & 0.21 & 0.33 \\
\hline & 120 & $3.9 \pm 0.3$ & $8.3 \pm 0.5$ & $1.0 \pm 0.0$ & $13.2 \pm 0.8$ & $45.6 \pm 1.0$ & $3.3 \pm 3.0$ & 0.20 & 0.31 \\
\hline \multirow[t]{2}{*}{ Na-acetate } & 90 & $0.5 \pm 0.0$ & $1.0 \pm 0.1$ & $0.2 \pm 0.0$ & $2.0 \pm 0.2$ & $49.0 \pm 0.0$ & $30.3 \pm 2.2$ & 0.05 & 0.11 \\
\hline & 120 & $0.8 \pm 0.2$ & $0.9 \pm 0.3$ & $0.3 \pm 0.1$ & $1.9 \pm 0.5$ & $48.0 \pm 0.0$ & $30.6 \pm 3.9$ & 0.05 & 0.11 \\
\hline \multirow[t]{2}{*}{ Ca-acetate } & 90 & $2.4 \pm 0.1$ & $3.7 \pm 0.3$ & $0.5 \pm 0.0$ & $6.7 \pm 0.4$ & $46.0 \pm 0.0$ & $19.1 \pm 0.1$ & 0.14 & 0.25 \\
\hline & 120 & $3.0 \pm 0.6$ & $3.6 \pm 0.0$ & $0.5 \pm 0.0$ & $7.2 \pm 0.6$ & $47.0 \pm 0.0$ & $18.6 \pm 5.4$ & 0.13 & 0.25 \\
\hline \multirow[t]{2}{*}{ Na-sulfate } & 90 & $0.7 \pm 0.0$ & $2.3 \pm 0.2$ & $0.3 \pm 0.0$ & $3.3 \pm 0.2$ & $50.7 \pm 0.4$ & $32.0 \pm 0.9$ & 0.12 & 0.18 \\
\hline & 120 & $0.5 \pm 0.0$ & $1.4 \pm 0.0$ & $0.2 \pm 0.0$ & $2.1 \pm 0.1$ & $49.1 \pm 1.5$ & $35.0 \pm 0.6$ & 0.10 & 0.15 \\
\hline \multirow[t]{2}{*}{ Ca-sulfate } & 90 & $2.5 \pm 0.2$ & $7.4 \pm 0.1$ & $0.8 \pm 0.0$ & $10.7 \pm 0.2$ & $47.4 \pm 0.2$ & $8.0 \pm 0.9$ & 0.19 & 0.27 \\
\hline & 120 & $2.2 \pm 0.0$ & $6.6 \pm 0.2$ & $0.7 \pm 0.0$ & $9.5 \pm 0.2$ & $42.2 \pm 1.5$ & $7.3 \pm 1.4$ & 0.19 & 0.27 \\
\hline
\end{tabular}

the control when the original sulfuric acid concentration was $90 \mathrm{mM}$ (Fig. 3C and Table 2). The Ca-sulfate had slightly inhibitory effect when the original sulfuric acid concentration was $120 \mathrm{mM}$. However, Ca-acetate caused a decrease in the concentrations and yields (Fig. 3B and Table 2). The results suggested that $\mathrm{Ca}$-acetate inhibited $\mathrm{ABE}$ fermentation. The different responses between the Ca salts were possibly due to their different solubility: i.e., Ca-citrate, Ca-sulfate and Caacetate salts were insoluble, slightly soluble, and soluble, respectively. Thus, most Ca-citrate and Ca-sulfate salts were precipitates on the bottom of the broth, which could not inhibit the ABE fermentation. Together with the results of enzymatic hydrolysis, we concluded that the completely insoluble salts formed during the neutralization process would inhibit the enzymatic hydrolysis of cellulosic materials; however, the soluble salts were inhibitors for the following $\mathrm{ABE}$ fermentation.

\section{Process conditioning}

The inhibitors for enzymatic hydrolysis of cellulosic materials and the following ABE fermentation can be broadly divided into two groups: (1) process inhibitors, which include different sugar and lignin degradation compounds, and the salts formed by acid-base reactions during pretreatment and neutralization processes; and (2) inherent inhibitors, which include monosaccharides and oligosaccharides, and butanol. ${ }^{14,30,31}$ Different detoxification methods, including lime, evaporation, peroxidase, adsorption using ion exchange resins, activated charcoal, and biological, have been used previously to reduce the process inhibitors associated with pretreatment and neutralization. ${ }^{19}$ However, process conditioning, e.g., selecting suitable pretreatment and neutralizing reagents and their proper concentrations, is a relatively simple method to avoid inhibition with salts in successful biofuel production from lignocellulosic materials.

A variety of acids have been investigated for pretreatment, such as sulfuric, oxalic, citric, acetic, and tartaric acids. ${ }^{17-19}$ The pretreated solids are usually separated from the liquid for the following hydrolysis using the buffer solutions. However, the separation and addition of buffer solution would increase the processing cost. Thus, direct neutralization for enzymatic hydrolysis and fermentation could improve this problem, and correspondingly, the inhibitory effect of formed salts must be considered. In this study, it seemed that the salts formed during the neutralization could be also used as the buffer solution for the enzymes, and some of the salts did not show inhibition on ABE fermentation. Sulfuric acid has been most widely used because it is inexpensive and effective. As shown in this study, the Ca-sulfate formed during sulfuric acid neutralization by using $\mathrm{Ca}(\mathrm{OH})_{2}$ as the neutralizing reagent did not inhibit the enzymatic hydrolysis of lignocellulosic materials, and also it had little inhibitory effect for ABE fermentation. Thus, the sulfuric acid as the pretreatment reagent and the $\mathrm{Ca}(\mathrm{OH})_{2}$ as the neutralizing reagent would be good option for process conditioning of biobutanol production from lignocellulosic materials. Certainly, it would be of interest to further investigate the neutralization process after pretreatment with other acids using different alkalis.

\section{Conclusions}

The Ca-citrate salt formed during neutralization had a severely inhibitory effect on cellulose hydrolysis, which was probably because of the adsorption interaction of cellulases on Ca-citrate solids. The soluble Na-citrate, -acetate and -sulfate inhibited $\mathrm{ABE}$ fermentation, but the insoluble Ca-citrate or slightly soluble Ca-sulfate did not. Interestingly, the Ca-sulfate did not show apparent inhibition on both hydrolysis and fermentation. The different inhibition capacities of the formed salts were probably due to their different solubilities. Thus, selecting suitable pretreatment and neutralization reagents is an alternative way to reduce inhibition with salts during the process of biofuel production from lignocellulosic materials.

\section{Conflicts of interest}

There are no conflicts to declare. 


\section{Acknowledgements}

This work was supported by Start-up Fund for Introduced Talents of Hebei Agricultural University, China (YJ201910), the Fundamental Research Funds for the Central Universities of China (Z109021701). Financial support also came from the projects: "Sustainable production concepts in the integrated biorefining industry (SusBioRef)" funded by the Academy of Finland, "New value chains for biorefining (A71029)" funded by the European Regional Development Fund, and "Development of efficient biomass conversion routes for biofuel production and utilization (CONVER-B)" funded by INNO-INDIGO/ Academy of Finland.

\section{References}

1 H. G. Qiu, L. X. Sun, J. K. Huang and S. Eozelle, Renewable Sustainable Energy Rev., 2012, 16, 3095-3104.

2 C. W. Zhang, H. Wen, C. J. Chen, D. Cai, C. H. Fu, P. Li, P. Y. Qin and T. W. Tan, Renewable Energy, 2019, 134, 44-53.

3 D. T. Jones and D. R. Woods, Microbiol. Rev., 1986, 50(4), 484-524.

4 S. B. Bankar, S. A. Survase, H. Ojamo and T. Granström, RSC Adv., 2013, 3, 24734-24757.

5 S. Banerjee, S. Mudliar, R. Sen, B. Giri, D. Satpute, T. Chakrabarti and R. A. Pandey, Biofuels, Bioprod. Biorefin., 2010, 4, 77-93.

6 G. Jurgens, S. Survase, O. Berezina, E. Sklavounos, J. Linnekoski, A. Kurkijärvi, M. Väkevä, A. van Heiningen and T. Granström, Biotechnol. Lett., 2012, 34(8), 1415-1434.

7 C. W. Zhang, S. Y. Pang, M. Lv, X. Y. Wang, C. S. Su, W. X. Gao, H. D. Chen, D. Cai, P. Y. Qin and T. W. Tan, Energy Fuels, 2019, 33, 1210-1218.

8 H. Wen, H. D. Chen, D. Cai, P. W. Gong, T. Zhang, Z. C. Wu, H. T. Gao, Z. Z. Li, P. Y. Qin and T. W. Tan, Biotechnol. Biofuels, 2018, 11, 134.

9 B. Yang, Z. Y. Dai, S. Y. Ding and C. E. Wyman, Biofuels, 2011, 2(4), 421-450.

10 M. Shafiei, R. Kumar and K. Karimi, in Lignocellulose-Based Bioproducts, ed. K. Karimi, Springer International Publishing, 2015, pp. 85-154.

11 C. E. Wyman, B. E. Dale, V. Balan, R. T. Elander, M. T. Holtzapple, R. S. Ramirez, M. R. Ladisch, N. S. Mosier, Y. Y. Lee, R. Gupta, S. R. Thomas, B. R. Hames, R. Warner and R. Kumar, in Aqueous Pretreatment of Plant Biomass for Biological and Chemical
Conversion to Fuels and Chemicals, ed. C. E. Wyman, John Wiley \& Sons, Ltd, 2013, pp. 239-259.

12 N. Mosier, C. Wyman, B. Dale, R. Elander, Y. Y. Lee, M. Holtzapple and M. Ladisch, Bioresour. Technol., 2005, 96(6), 673-686.

13 F. Hu and A. Ragauskas, BioEnergy Res., 2012, 5, 1043-1066. 14 T. Ezeji, N. Qureshi and H. P. Blaschek, Biotechnol. Bioeng., 2007, 97, 1460-1469.

15 N. Qureshi, T. C. Ezeji, J. Ebener, B. S. Dien, M. A. Cotta and H. P. Blaschek, Bioresour. Technol., 2008a, 99, 5915-5922.

16 I. S. Maddox, E. Steiner, S. Hirsch, S. Wessner, N. A. Gutierrez, J. R. Gapes and K. C. Schuster, J. Mol. Microbiol. Biotechnol., 2000, 2, 95-100.

17 L. Qin, Z. H. Liu, N. Z. Li, B. E. Dale and Y. J. Yuan, Bioresour. Technol., 2012, 112, 319-326.

18 O. M. Kwon, D. H. Kim, S. K. Kim and G. T. Jeong, Algal Res., 2016, 13, 293-297.

19 T. A. L. Silva, H. D. Z. Zamora, L. H. R. Varão, N. S. Prado, M. A. Baffi and D. Pasquini, Waste Biomass Valorization, 2018, 9, 2191.

20 A. Hirsch and E. Grinsted, J. Dairy Res., 1954, 21, 101-110.

21 J. Zhu, L. Shi, L. Zhang, Y. Xu, Q. Yong, J. Ouyang and S. Yu, Bioprocess Biosyst. Eng., 2016, 39(10), 1619-1626.

22 H. Zhang, J. Zhao, Z. Lin and H. Huang, Chin. J. Bioprocess Eng., 2011, 9(1), 1-4.

23 B. Yu and H. Chen, Bioresour. Technol., 2010, 101, 91149119.

24 B. C. Min and B. V. Ramarao, Bioprocess Biosyst. Eng., 2017, 40(6), 799-806.

25 H. Liu, J. Sun, S. Y. Leu and S. Chen, Biofuels, Bioprod. Biorefin., 2016, 10(5), 648-663.

26 S. Y. Li, R. Srivastava, S. L. Suib, Y. Li and R. S. Parnas, Bioresour. Technol., 2011, 102(5), 4241-4250.

27 M. Yang, S. Kuittinen, J. Vepsäläinen, J. Zhang and A. Pappinen, Bioresour. Technol., 2017, 243, 126-134.

28 C. W. Zhang, H. D. Chen, N. An, C. S. Su, M. Lv, S. Y. Pang, X. Y. Wang, D. Cai and P. Y. Qin, Ind. Crops Prod., 2019, 139, 111500.

29 N. Qureshi, B. C. Saha, R. E. Hector and M. A. Cotta, Biomass Bioenergy, 2008b, 32, 1353-1358.

30 N. R. Baral and A. Shah, Appl. Microbiol. Biotechnol., 2014, 98, 9151-9172.

31 H. B. Klinke, A. B. Thomsen and B. K. Ahring, Appl. Microbiol. Biotechnol., 2004, 66, 10-26. 